Transfixed by the bird's splendor, she forgot everything until, next to her, she heard the metallic click of Ruth's rifle.

Seeing Ruth take aim, she felt a blind fury and, lunging violently, grabbed for the rifle.

A shot rang out as she saw the egret begin its ascent to safety.

Then came the screaming! Screans like nothing Francie had ever heard, worse even than the screams of pigs at slaughter time. She followed her screaming cousin's frozen stare.

There was nothing left. Where Jamie's face had been, there was now a mass of pulpy redness. A great red-black hole in the midale of it all gaped one-sidedly as a hideous sound burbled forth through crimson froth.

Francie looked and saw no more.

When they found the children, Ruth kept pointing at Francie, "She done it; she done it," she said over and over.

Francie was stiff; eyes as glazed as the dead fishes; limbs as hard and unbending as the cocked rifles.

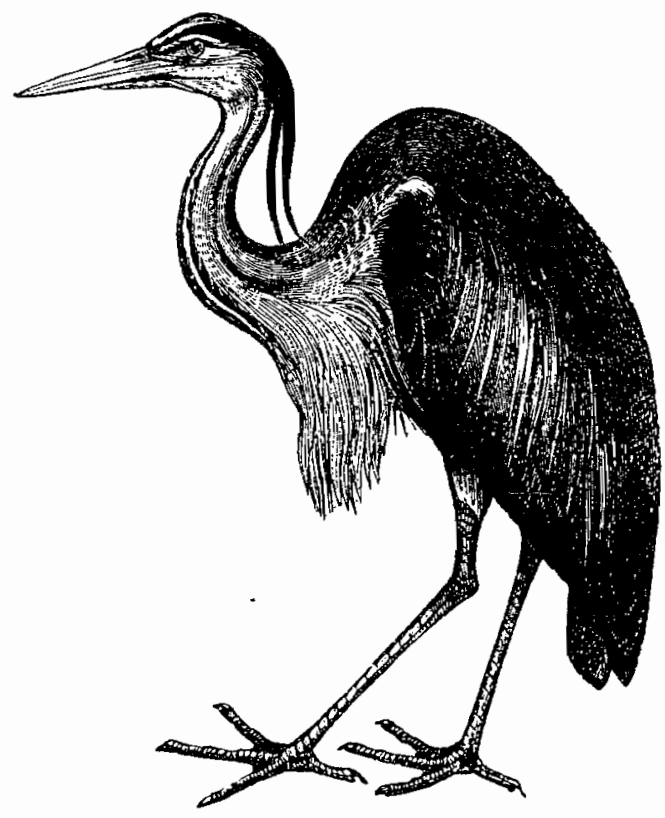

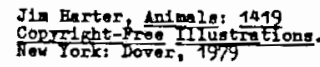

\section{ANTHROCENTRISM: A HUMAN FALLACY}

\author{
MARK SUNLIN \\ Saratoga, California
}

Webster's dictionary defines "anthropocentrism" as "considering man to be the most significant entity in the universe; interpreting or regarding the world in terms of human values." This is, not surprisingly, a highly cormon viewpoint among members of the human race; in fact, many people may never have considered any other view.

Anthropocentricity is based on the belief that there is a firm dividing line between humans and non-humans. This belief is reaffirmed by such practices as the belittling use of inanimate pronouns such as "it," "which," and "that" in describing animals. For example, "Susan took her dog to the groomers to have its nails cut." This is not merely a question of terminology, for using these inanimate pronouns to refer to animals encourages us to treat animals like inanimate objects. It is easier to tolerate a trapper "harvesting" an it or a researcher "sacrificing" an it, than to face up to their killing a him or her.

The fear of embarrassment--"you're just sentimental and anthropomorphizing!"--associated with being compassionate beyond the human race is one of two main factors which entrench and promote anthropocentricity. You would think that compassion would be the last emotion requiring apology, yet many people cringe at being compassionate to animals and consider a dispassionate view of the animal world to be only sensible and mature.

The other factor promoting anthropocentricity is that humans, as a rule, very much enjoy considering themselves to be unique, superior, and the powerful rulers over all the other creatures on earth. Playing the role of gods is not easily given up. In ancient Greek mythology, it was through consuming ambrosia that the gods were maintained as gods; if they went without it even for a day, they would become weak and lose their immortality. Anthropocentricity is a kind of ambrosia for the human ego. But like the

$$
\text { (Continued on page 54) }
$$




\section{(Continued from page 22)}

ancient Greek form, it is in reality only a myth-and in the end, the gods themselves faded away.

We the monkey people, are the greatest folk in all the jungle. We know this is true because we always say it is true.

from the film version of Rudyard Kipling's The Jungle Book

\section{LETTERS}

To the editors:

The over-intellectualized writing of Charlie Blatz ["Why (Most) Fumans Are More Important than Animals," Between the Species, I/4 (1985) ] leads him repeatedly to the apparently conforting (to him) realization that we really don't know all the facts, so let's not be too hasty about taking our boot-heels off the necks of the exploited. We can't know all the repercussions of a cultural transition to veganism, so let's keep on consuning the products of factory farming. Etc.

Pardon my expression of human emotion in an academic journal, but doesn't tin-man Blatz understand that all the facts are never in? That we always make our practical, ethical decisions on an incomplete information base? That the heart as well as the head Eactors into the way we choose to live our lives? And that "lack of complete information"--about nuclear proliferation, the government's latest dirty little war, animal abuse, sexual violence, you name it--is always used by the politically timid, the nonexploited, and the beneficiaries of exploitation as an excuse for continued cooperation with the status quo?

I suggest that Professor Blatz make a date with Dorothy during the next tornado season in Kansas. Perhaps he can get from the wizard of $\mathrm{Oz}$ what he so glaringly needs to balance his writing on the rights of nonhuman arimals.

BILLY RAY BOYD

San Francisco, California
Opinion

JOHN SIOCKWELI,

The Schweitzer Center

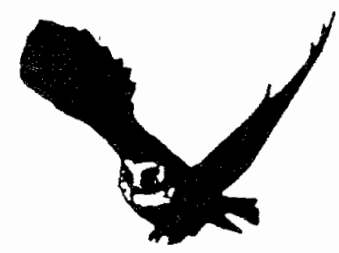

An ecological science of environmental administration is defined by Pierre Dansereau in his Inscape and Landscape (1973). Dansereau suggests that images, inscapes, mindscapes--partly composed from our knowledge of the natural world--profoundly affect the human instruments (tools and forms of organization) which, as human power grows, increasingly condition the landscape. Management is one such instrument. Ecologically and ethically uninformed, its images increasingly model a devastated planet. Science, technology, and human populations follow suit, with the result that human life itself grows more precarious and--we may add (and this is outrageous!)--nature finds itself being phased out.

Dansereau urges,

The need to build a new world is now a necessity, not the utopia that it may have seemed in 1914 or even in 1939. This is a work of the imagination, and imagination reaches out to hidden dimensions. . - In other words, the richness of our inscapes is a preliminary to a good management of our landscapes.

If we saw the world through the eyes of Ajax, we would rush perhaps to confront our challenges as did that hero-only to find ourselves slaughtering animals instead. So, it does make a difference which mindscapes we inhabit.

In examining either animal liberation or the structure of managerial decisions (which latter Dansereau has said suffer from an unecological picture of the world), it is not possible to completely dispense--as so many attempt to do- with analysis of class.

In The Hidden Injuries of Class (1972), Richard Sennett shows how it is that in America and variedly elsewhere comparative judgments of persons' abilities serve to maintain 